\title{
INOVASI MEDIA ONLINE DALAM MENGHADAPI PERSAINGAN MEDIA MASSA DI KOTA BENGKULU
}

\author{
Oleh: \\ FERIZAL ADEK, YANTO, EVI LORITA \\ Program Studi Ilmu Komunikasi Fakultas Ilmu-Ilmu Sosial \\ Universitas Dehasen Bengkulu
}

\begin{abstract}
The aim of his study is to know innovation communication and innovation as the process of renewal, utilization, development by creating new things different from before. Innovation also can be interpreted new invention in technology or ability in introducing new findings different from preexisting. Broadly speaking the mass media is divided into three namely print media, audited electronic media, and audio-visual electronic media. Online media is an online journalistic product that is defined as reporting facts or events that are produced and distributed over the internet. This study uses qualitative method that produces descriptive data of how the words written or oral from observation and observation techniques of data collection conducted through an observation with the recording of the state or behavior of the target object, methodologically the reason for observation user is the observation optimizing the ability of the writer in terms of motives, beliefs, attention, unconscious behaviors and habits and the media can be interpreted with the tool channel while online term materials in the internet which means an information that can be accessed with internet network. The result conducted that the next researcher will discuss from the analysis conducted can be seen that Online Media Innovation in Facing Mass media Competition in Bengkulu City. Communication Planning Innovation is used as a guide for online media, especially bengkulunews.co.id become reference for important online media innovation in facing mass media of Bengkulu City. Cyber media in Indonesia are also part of freedom of speech, freedom of expression and freedom of the Press. Cyber media is any form of media that uses inlet and carry out the activities of journalism, and meet the Press Law and standard press companies in the set.
\end{abstract}

\section{Keywords: innovation, online media, mass media, communication}

\section{PENDAHULUAN}

Perkembangan dan kemajuan teknologi telah memfasilitasi kehidupan sehari-hari masyaraakat dunia. Ilmu dan teknologi telah memungkinkan untuk menjangkau dunia yang luas ini. Media elektronik seperti televisi, internet, dan media interaktif lainnya telah dapat membantu mengetahui dunia ini lebih dekat. Fenomena jurnalisme online sekarang ini menjadi contoh menarik. Di sisi lain, jurnalisme online juga memungkinkan wartawan untuk terusmenerus meng-up date (memperbaharui) informasi yang ditampilkan seiring dengan temuan-temuan baru yang ada di lapangan. (Saifullah-2012).

Perkembangan Media online saat ini semakin mengalami kemajuan dari sisi tampilan ataupun dalam kecepatan mengakses website. Masyarakat Provinsi Bengkulu kini mulai memberikan apresisasi keberadaan media online yang kini tumbuh pesat. Dampak positif lainnya dengan hadirnya media online ini, membuka inspirasi bagi masyarakat untuk terlibat langsung dalam kegiatan jurnalisma atau kewartawanan di media online. Bagi masyarakat pemula, menjadi jurnalis pada media online relatif dirasakan mudah dan 
sederhana selain menyalurkan hobby dalam pekerjaan tulis menulis dengan berbagai inovasi yang ada saat ini.

Apalagi dengan perkembangan teknologi, Media online saat ini terus mengalami inovasi dan kreasi. Pada awal perkembangan media online, masyarakat hanya disuguhkan dengan tampilan tulisan. Saat ini, masyarakat sudah dapat mendengarkan audio visual dan faktual. Sudah dapat melihat gambar bergerak dari aktualisasi berita yang disuguhkan. Hal ini merupakan suatu inovasi yang mencerahkan bagi dunia jurnalisme ataau media massa. (Kompasiana.com).

Kemajuan zaman dengan teknologinya yang semakin canggih, memungkinkan masyarakat lebih mudah mengakses informasi melalui media online. Di Provinsi Bengkulu khususnya, media online sekarang ini terus mengalami kemajuan. Salah satu indikatornya adalah semakin menjamurnya media massa yang menjadi bagian penting dalam mensukseskan program-program pembangunan pemerintahan.

Satu contoh nyata adalah hadirnya media online yang sebelumnya merupakan media cetak. Media online yang beralih dari media cetak tersebut bukan berarti menghilangkan media cetaknya. Namun media cetak tersebut melahirkan alternative baru dalam bisnis media massa, yakni lahirnya media online sebagai bagian dari ekspansi bisnisnya. (kompasiana. com/nugrohotriputra87).

Perkembangan media online khususnya di Bengkulu mengalami kemajuan yang cukup pesat. Dari era Tahun 2000-an, keberadaan media online belum terlalu dikenal di Ibu Kota Provinsi Bengkulu. Media online baru muncul pada pertengahan tahun 2011. Pada tahun inipun belum banyak media online yang beredar di kota Bengkulu, belum tumbuh dengan pesat seperti saat ini. Penulis mencatat, saat ini ada sekitar belasan media online yang ada di kota Bengkulu.

Berikut beberapa media online yang ada di Kota Bengkulu :
1. Kupasbengkulu.com

2. Bengkulu Ekspres.com

3. Antara.com

4. Bengkulunews.co.id

5. Bengkulu Today.com

6. Pedoman Bengkulu.com

7. Rakyat Bengkulu.com

8. RBTV.co.id

9. Rakyat Merdeka online.com

10. Nusantara.com

11. Gerbang.com

12. Progres.co.id

13. Radar Bengkulu.com

14. Bengkulu bisnis.com

15. Suara Bengkulu.com

16. Redaksi Bengkulu.com

(Sumber : bengkulunews.co.id 2016).

Dengan adanya teknologi ini masyarakat mulai memahami dan manfaatkan teknologi melalui media online dan media online mulai bermunculan di Kota Bengkulu. Masyarakat atau pembaca mulai mengakses informasi jadi lebih mudah dan cepat, untuk mengetahui informasi dan berita yang terbaru di seputaran Provinsi Bengkulu maupun luar Provinsi Bengkulu. Sehingga azaz manfaat teknologi yang ada, dapat dirasakan oleh pembaca dan masyarakat Bengkulu.

Media online yang hadir sejatinya tidak hadir dengan sendirinya. Ada beberapa media cetak maupun televisi yang merambahkan lini bisnisnya ke dunia online. Diantara media cetak maupun televisi yang ada di Kota Bengkulu yang merambah ke dunia media online adalah, Rakyat Bengkulu (RB), cetak merambah dunia online dengan nama Rakyat Bengkulu.com, Bengkulu News yang awalnya merupakan media cetak mingguan melebarkan sayap bisnisnya ke media online dengan nama Bengkulunews.co.id, Bengkulu Ekspres cetak merambah dunia online dengan nama Bengkulu Ekspres.com, serta Rbtv yang semula Media televisi merambah dunia online dengan nama Rbtv.co.id,

Radar Bengkulu Media cetak kini juga merambah ke media online nama Radar Bengkulu.com. Semua itu dampak 
dari perkembangan media online di kota Bengkulu. Dengan banyaknya bermunculan media online di Kota Bengkulu, tidak menyurutkan Media cetak ini tutup atau menghilang, melainkan media cetak tersebut membuka linis bisnis online-nya dengan membuka portal media online-nya. Dengan demikian dunia media online khususnya dalam persaingan media masaa di kota Bengkulu (Sumber: Survei Bengkulu news.co.id).

Dengan berkembangnya media online di kota Bengkulu hal ini membuat penulis penasaran untuk menjadikan hal ini sebagai Penelitian. Penulis ingin mengetahui inovasi apa yang dilakukan media online khususnya yang bereformasi dari media cetak menjadi media online. Penulis memfokuskan meneliti di media online Bengkulu News.co.id. Alasan penulis meneliti di Bengkulu News adalah media cetak mingguan yang juga merambah menjadi media online hal ini, memudahkan penulis untuk mendapatkan data dan informasi yang dibutuhkan. Selain itu juga penulis ingin mengangkat inovasi yang dilakukan Bengkulu news.co.id yang semulanya adalah media cetak mingguan. Hal ini merupakan sesuatu yang membanggakan karena kali pertama media cetak mingguan yang memiliki media online sendiri.

Secara umum di Indonesia permasalahan dalam media online adalah terletak pada sisi persaingan baik secara bisnis pemasaran, konten tayangan, maupun idealisme informasi. Ketiga hal itu adalah untuk menjadi tolak ukur untuk melihat perkembangan media online atau istilah sederhananya adalah ujung tombak dalam persaingan media online. Inovasi media online diperlukan dikarenakan setiap media online yang ada di kota Bengkulu yakni Media online Bengkulu News co.id dan Kupasbengklulu,com, Bengkulu Today.com, Pedoman.com, Rakyat Merdeka Online com (RMOL), Progres.com.

Setiap media online ini yang ada di Kota Bengkulu ini juga memiliki standar kerja yang tentu ada perbedaan penayangan maupun konten beritanya dengan model media online yang sudah berada dalam lingkup garis media nasional. Permasalahannya adalah ketika media online itu mengungkapkan suatu konten berita media online ini bermacam sudut pandang yang ditayangankan oleh jurnalis atau wartawan media online itu berdasarkan subyektifitas atau objektifitas.

Media online bengkulu news.co.id ini sudah hampir tiga tahun berdiri di Kota Bengkulu dan sejak media online bengkulunews.co.id sudah menanyangkan informasi atau berita untuk masyarakat,maka media ini sudah di kenal dan percaya oleh masyarakat pemberitaan untuk dijadikan pedoman dalam memberita suatu informasi ,karena menurut masyarakat media online ini untuk memberikan informasi sebagai acuhan dan fakta informasi yang di tayangkannya, sehingga masyarakat dan Publik mulai mempercayai pemberitaan dalam mengkritik dalam sajian pemberitaannya.

Asumsi sederhana dalam penelitian yang akan dilakukan oleh penulis adalah melihat bagaimana sebuah media online sekelas Bengkulunews.co.id melakukan suatu inovasi dalam persaingan media massa. Penulis kembali menekankan bahwa yang diteliti disini adalah media onlinenya. Penulis ingin mengetahui bagaimana Bengkulu News yang juga merupakan media cetak atau sering disebut koran mingguan yang terbitnya setiap minggu ini, melakukan inovasi dalam media onlinenya sehingga bisa menghadapai persaingan media massa yang lumayan ketat dan bersaing di Kota Bengkulu.

Dalam penelitian yang akan dilakukan penulis ini memfokuskan pada inovasi media online Bengkulu News.co.id Dalam menghadapi persaingan media masaa yang ada di Kota Bengkulu khususnya inovasi penayangan ataupun tampilan konten berita. Sehingga menarik masyarakat atau pembaca untuk mengetahui informasi dengan melakukan inovasi masing masing konten berita, 
sehingga para kunjungan media online menjadi tinggi retingnya dan viewere (kunjungan) dan untuk sisi tampilan tayangan juga salah satu menarik pembaca.sehingga pembaca tertarik untuk melakukan pemasangan Iklan dalam portal media itu tersebut.

Dengan cara menampilkan ide dan gagasan yang dianggap baru oleh seorang untuk berminat membaca portal media online tersebut dan yang lain-lain tidak menjadi focus ataupun sasaran penelitian. Ruang lingkup permasalahan maupun inti masalah yang akan diteliti penulis letakkan pada bagian rumusan masalah. Tujuan dari penulisan rumusan masalah itu agar pembaca tidak rancu dalam memahami penelitian yang dilakukan oleh penulis.

Melalui penelitian ini penulis ingin melihat dan mengetahui Inovasi yang dilakukan bengkulunews.co.id dalam persaingan media massa di kota Bengkulu.

\section{METODE PENELITIAN}

Penelitian kualitatif adalah penelitian yang bermaksud untuk memahami fenomena tentang apa yang dialami oleh subjek penelitian misalnya perilaku, persepsi, motivasi, tindakan dan lain-lain. Secara holistik (umum), dan dengan cara deskripsi dalam bentuk kata-kata dan bahasa, pada suatu konteks khusus yang alamiah dan dengan memanfaatkan berbagai metode alamiah.

Pola pikir dalam penelitian kualitatif adalah pola pikir induktif. Pola pikir induktif merupakan suatu cara berfikir dengan mendasarkan pada pengalamanpengalaman yang diulang-ulang, atau suatu cara atau jalan yang dipakai untuk mendapatkan ilmu pengetahuan ilmiah dengan bertitik tolak dari pengamatan atas hal-hal atau masalah yang bersifat khusus, kemudian menarik pada kesimpulan yang bersifat umum.

Data yang akan dihasilkan adalah deskriptif. Menurut Whitney, metode deskriptif adalah pencarian fakta dengan interpretasi yang tepat. Selanjutnya Moh. Nazir menerangkan bahwa penelitian deskriptif mempelajari masalah-masalah dalam masyarakat, serta tata cara yang berlaku dalam masyarakat serta situasisituasi tertentu, termasuk tentang hubungan kegiatan-kegiatan, sikap-sikap, pandanganpandangan, serta proses yang sedang berlangsung dan pengaruh suatu fenomena.

Informan penelitian adalah orang yang dimanfaatkan untuk memberikan informasi tentang situasi dan kondisi latar belakang penelitian (Moleong 2000 : 97). Informan merupakan orang yang benar-benar mengetahui permasalahan yang akan diteliti.

Dalam penelitian ini terdapat 2 informan diantaranya:

1. Informan kunci, yaitu orang-orang yang sangat memahami permasalahan yang diteliti. dalam penelitian ini peneliti akan bertanya langsung kepada Erlan Oktriyandi,S.H. selaku Pimpinan Umum Bengkulu News.co.id

2. Snowball atau bola salju Informan yang dipilih merupakan hasil rekomendasi dari informan sebelumnya. Ini umumnya digunakan bila peneliti tidak mengetahui dengan pasti orang-orang yang layak untuk menjadi sumber. Salah satu cara yang bisa digunakan adalah dengan meminta rekomendasi dari seseorang. Dari seorang informan, jumlah sumber data dapat berlipat ganda jumlahnya. Seperti bola salju yang menggelinding.

Menurut Lofland dan Lafland, sumber data utama dalam penelitian kualitatif ialah kata-kata, dan tindakan, selebihnya adalah data tambahan seperti dokumen dan lain-lain. Berkaitan dengan hal itu pada bagian ini jenis datanya dibagi ke dalam kata-kata dan tindakan, sumber data tertulis, foto, dan statistik.

Mengacu pada pendapat tersebut, jenis data yang akan dikumpulkan dalam penelitian ini adalah data primer dan data sekunder yang diambil dari dokumentasi dan bahan kepustakaan serta diperkuat oleh data tertier berupa kamus, ensiklopedia dan internet. 


\section{Sumber Data Primer}

a. Situation yaitu data yang diperoleh dari gambaran situasi ataupun kondisi yang berhubungan dengan masalah yang dibahas oleh penulis.

b. Place yaitu lokasi atau tempat yang dijadikan sebagai obyek penelitian oleh peneliti dimana lokasi tersebut dapat memberikan informasi terkait dengan data yang dibutuhkan peneliti. yakni lokasi yang menjadi obyek peneliti adalah di kantor media online Bengkulu news.co.id yang bertempat di Kelurahan Padang Harapan kota Bengkulu.

c. Activity yaitu keativan dari suatu kegiatan. Jadi aktivitas diartikan sebagai segala kegiatan yang dilakukan oleh penulis baik diluar maupun didalam kantor tentang persoalan terhadap segala sesuatu selama proses kegiatan di media online tersebut.

\section{Sumber Data Sekunder}

Adapun sumber data yang merupakan asal data diperoleh dari bahan kepustakaan yang bersumber pada buku-buku, kitabkitab dan beberapa bentuk karya ilmiah lain yang ada kaitannya dengan pokok permasalahan. Teknik Pengumpulan Data Penelitian ini menggunakan beberapa cara pengumpulan data, yaitu:

\section{Wawancara}

Menurut Moleong, wawancara adalah "percakapan dengan maksud tertentu yang dilakukan dua pihak, yaitu "pewawancara"e (interviewer) yang mengajukan pertanyaan dan yang diwawancaraie (interviewee) yang memberikan jawaban atas pertanyaan. Melalui teknik ini, akan digali data selengkap-lengkapnya tentang apa yang diketahui, apa yang dialami informan. wawancara dalam suatu penelitian bertujuan mengumpulkan keterangan tentang kehidupan manusia dalam suatu masyarakat serta pendirian-pendirian itu merupakan suatu pembantu utama dari metode observasi (pengamatan).
Alat bantu yang akan dipakai adalah alat perekam, pedoman wawancara, kamera serta laptop untuk membuat transkrip wawancara. Dalam hal ini, peneliti terlebih dahulu menentukan siapa saja yang akan diwawancarai serta menyiapkan secara garis besar daftar pertanyaan yang sesuai dan berkaitan dengan judul penelitian.

\section{Observasi}

Adalah teknik pengumpulan data yang dilakukan melalui suatu pengamatan, dengan disertai pencatatan-pencatatan terhadap keadaan atau perilaku objek sasaran.

Secara metodologis alasan bagi penggunaan observasi ialah: observasi mengoptimalkan kemampuan peneliti dari segi motif, kepercayaan, perhatian, perilaku tak sadar, kebiasaan, dan sebagainya; observasi memungkinkan pengamat untuk melihat dunia sebagaimana dilihat oleh subjek penelitian, hidup pada saat itu, menangkap arti fenomena dari segi pengertian subjek, menangkap kehidupan budaya dari segi pandangan dan panutan para subjek pada keadaan waktu itu; observasi memungkinkan peneliti merasakan apa yang dirasakan dan dihayati oleh subjek, sehingga memungkinkan pembentukan pengetahuan yang diketahui bersama, baik dari pihaknya maupun dari pihak subjek.

\section{Teknik Analisis Data}

Analisis data Adalah proses mencari dan menyusun secara sistematis data yang diperoleh melalui wawancara, catatan lapangan, dan bahan-bahan lain, sehingga dapat mudah dipahami, dan temuannya dapat diinforrmasikan kepada orang lain. Dilakukan dengan mengorganisasikan data, menjabarkannnya ke dalam unit-unit, melakukan sintesa, menyusun ke dalam pola, memilih dan membuat kesimpulan.

Analisis data merupakan tahap yang menentukan dalam penelitian kualitatif. Analisis data merupakan suatu proses penafsiran data untuk memberikan makna, menjelaskan pola atau kategori dan mencari 
hubungan antar konsep. Untuk teknik analisis studi kasus, peneliti menggunakan logika Pattern Matching atau Penjodohan Pola. Logika seperti ini membandingkan pola yang di dasarkan atas empiri dengan pola yang diprediksikan (atau dengan beberapa prediksi alternative).

Jika kedua pola tersebut ada persamaan, hasilnya dapat menguatkan validitas internal studi kasus yang bersangkutan. Dalam proses analisis data dilakukan secara simultan dengan pengumpulan data, artinya peneliti dalam mengumpulkan data juga menganalisis data yang diperoleh di lapangan.

\section{Reduksi data}

Reduksi data Merupakan proses pemilihan, pemusatan perhatian, penyederhanaan, pengabtsrakan dan transparansi data kasar yang muncul dari catatan lapangan. Oleh karena itu langkahlangkah yang dilakukan oleh peneliti adalah melakukan perampingan data dengan cara memilih data yang penting kemudian menyederhanakan dan mengabstraksikan.

Dalam reduksi data ini, peneliti melakukan proses living in (data yang terpilih) dan living out (data yang terbuang) baik dari hasil pengamatan, wawancara maupun dokumentasi. Proses reduksi data ini tidak dilakukan pada akhir penelitian saja, tetapi dilakukan secara terus-menerus sejak proses pengumpulan data berlangsung karena reduksi data ini bukanlah suatu kegiatan yang terpisah dan berdiri sendiri dari proses analisis data, akan tetapi merupakan bagian dari proses analisis itu sendiri.

\section{Penyajian Data}

Penyajian Data merupakan suatu proses pengorganisasian data sehingga mudah dianalisis dan disimpulkan. Penyajian data dalam penelitian ini berbentuk uraian narasi serta dapat diselingi dengan gambar, skema, matriks, tabel, rumus, dan lain-lain.
Hal ini disesuaikan dengan jenis data yang terkumpul dalam proses pengumpulan data, baik dari hasil observasi, wawancara, maupun studi dokumentasi. Penyajian data ini merupakan hasil reduksi data yang telah dilakukan sebelumnya agar menjadi sistematis dan bisa diambil maknanya, karena bisaanya data yang terkumpul tidak sistematis.

\section{Verifikasi dan Kesimpulan Data}

Verifikasi dan Kesimpulan Data merupakan langkah ketiga dalam proses analisis. Kesimpulan yang pada awalnya masih sangat tentatif, kabur, dan diragukan, maka dengan bertambahnya data, menjadi lebih grounded.

\section{HASIL PENELITIAN DAN PEMBAHASAN}

Pengumpulan data dalam penelitian di mulai 16 Mei sampai 20 Juni 2017 selama melakukan penelitian banyak yang di temukan hal hal yang baru yang sangat penting dan menyempurnakan hasil dari penelitian ini dan peneliti memiliki beberapa informan dikelompokan menjadi dua yakni informan pokok dan informan kunci, yaitu untuk mengetahui analisis inovasi media online dalam menghadapi persaingan media massa Kota Bengkulu.

Informan pokok adalah Erlan Oktariandi berusia 36 tahun, Erlan seharihari bekerja sebagai pimpinan umum Bengkulu News.co.id. Peneliti memilih informan pokok dengan alasan ia lebih banyak terlibat dalam mengelolah Perusahan Bengkulu news.co.id ada pun hasil penelitian mengenai kraterlistik informan pokok di tinjau dari usia, pendidkan dan jabatan Bengkulu news.co.id

Sedangkan informan kunci dalam penelitian ini adalah masyarakat yang sering yang melibatkan diri Bengkulu News.co.id yang merupakan seorang pimpinan redaktur sebagai informan kunci.

Profil Informan kunci Saudara Demon Fajri berusia 27 tahun yang bekerja sebagai Redaktur Pelaksana Bengkulu 
News.co.id dan yang beralamat jalan rinjani, Kelurahan Jembatan Kecil, Kecamatan Singaran Pati, Kota Bengkulu. Setelah melakukan penelitian ditemukan hasil:

1. Peneliti sudah menemui apa yang dilakukan oleh Bengkulu news.co.id tentang inovasi dalam portal web Bengkulu news.co.id berita yang di tampilkan dan tayangan telah memiliki ciri kas dalam suatu pemberitaan yang di sajikan dalam media online untuk pembaca maupun public yang menjadi berita tercepat dan acuan, refensi untuk masyarakat maupun Pemerintah setempat.

2. Semangkin banyak informasi dan berita di tayangkan di portal web Bengkulu News.co,id maka semangkin banyak pula view atau pengunjung membaca berita yang di sajikan, baik itu berita dari daerah maupun berita sekitar Kota Bengkulu yang di liput oleh jurnalis Bengkulu News.co.id. Hal ini untuk mendapatkan suatu berita dari lapangan baik itu berita peristiwa, kriminal, politik, serta Pemerintahan Provinsi dan Kota harus jelas dan fakta serta akruat harus segera di kirim berita melalui email redaksi sehingga berita yang masuk ke dapur redaksi dapat di olah menjadi suatu berita yang menarik sehingga saat di tayangkan maka pembaca cepat mengetahui informasi dari portal web Bengkulu News.co.id.

Berdasarkan hasil penelitian yang dilakukan maka selanjutnya peneliti akan membahas dari analisis tersebut yang dilakukan informan dapat dilihat bahwa inovasi media online dalam menghadapi persaingan media massa Kota Bengkulu.peneliti menggunakan teori Perencanaan Komunikasi Inovasi untuk menganalisis metode yang digunakan dalam penelitian ini adalah Perencanaan Komunikasi Inovasi digunakan sebagai pedoman untuk media online khususnya Bengkulu News.co.id menjadi acuan untuk penting Inovasi media online dalam menghadapi media massa kota Bengkulu.

Dalam hal ini peneliti membahas tentang indicator inovasi media online dalam menghadapi persaingan media massa kota Bengkulu, maka yang mengindikatori sebuah inovasi adalah sebagai berikut :

1. Ketepatan dan kelengkapan analisis fakta dan situasi.Perencanaan inovasi yang baik harus mengungkapan hasil analisis fakta da situasi yang lengkap, mencakup aspek potensi alam, potensi sumber daya manusia (SDM ),kelengkapan, pranda sosial,keamanan. Setelah diamati peneliti bahwa Bengkulu News.co.id belum sepenuhnya melakukan ketepatan dan kelengkapan dan situasi inovasi yang baik dalam menampilan suatu berita,karena baik di lihat sumber daya manusia yang ada Bengkulu News.co.id masih mengalami kekurangan gagasan dan ide dalam mengahadapi persaingan media massa di kota Bengkulu.

2. Penetapan masalah berdasarkan kebutuhan khalayak sasaran, Hasil analisis fakta dan keadaan akan menghasilkan masalah tertentu. Boleh jadi masalah yang akan timbul sangat banyak dan beragam.karena itu sumber atau agen perubahan perlu memprioritaskan masalah-masalah konkret yang telah menjadi tujuhan perubahan. Setelah diamati peneliti penetapan masalah berdasarkan kebutuhan khalayak sasaran maka hasil yang ditemui Bengkulu news.co.id masih belum mampu memenuhi kebutuhan khalayak sasaran, dikarenakan keterbatasab fasilitas, informasi dan keluhan masyarakat terhadap kebutuhan khalayak sasaran tentang berita berita kebutuhan public.

3. Kejelasan dan jaminan fleksibilitas, yaitu perencanaan harus jelas dan tegas sehingga tidak menimbulkan keragu-raguan dalam pelaksanaan, selain itu perencanaan juga harus 
memiliki peluang dimodifikasi sesuai dengan perkembangan yang terejadi demi mencapai keberhasilan yang lebih besar.

Setelah diamati penelitian maka kejelasan dan jamin fleksibilitas belum bisa di jamin karena dalam melakukan inovasi Bengkulu news,co.id masih keraguaan dalam melakukan inovasi sehingga belum bisa mencapai target keberhasilan untuk saat ini.

4. Merumuskan tujuan dan solusi masalah yang menjanjikan keberhasilan yang memuaskan, jadi, tujuan inovasi yang ingin dicapai harus dapat menghasilkan perbaikan kesejeterahaan dan kepuasan batin khalayak sasaran, Perumusan tujuhan yang mampu memenuhi kebutuhan khalayak sasaran akan juga mampu menumbuhkan motivasi khalayak sasaran untuk berpartisipasi di dalam tiap kegiatan. Setelah diamati peneliti ternyata Bengkulu news.co.id dalam perumusan tujuan dan solusi yang telah dilakukan belum berhasil secara utuh seperti kesejahteraan dan kepuasan batin khalayak sasaran sehingga masih kurang partisipasi masyarakat dalam kegiatan yang dilakukan Bengkulu news.co.id

5. Menjaga keseimbangan kepentingan yang berarti bahwa perencanaan inovasi harus mampu memenuhi kepentingan sebagai besar khalayak sasaran. Setelah diamati peneliti masih mementingkan kepentingan pribadi dari pada kepentingan khalayak sasaran hal ini dapat di lihat dari segi berita yang di sampaikan dan penekanan pada kinerja yang dilakukan para wartawan di lapangan supaya berita yang didapatkan ada timbal balik untuk perusahaan.

6. Pekerjaan yang jelas,artinya perencanaan inovasi harus disusun secara jelas.Kejelasan dalam hal ini mencakup komponen khalayak sasaran,tujuhan,waktu dan tempat pelaksanaan, metode yang akan digunakan,tugas dan indicator keberhasilan kegiatan. Setelah diamati dalam melakukan inovasi Bengkulu news,co,id belum melakukan persiapan secara matang sehingga perencanaan inovasi belum tersusun secara jelas seperti tugas tanggung jawab semua pihak yang terlibat dalam melakukan inovasi, sehingga indicator keberhasilan masih mengambang.

7. Perencanaan sebagai proses yang berkelanjutan, mulai dari perumusan dan pensolusian masalah sampai tindakan selanjutnya. Setelah diamati peneliti Bengkulu news.co.id belum melakukan tindakan dalam perumusan masalahan Selama melakukan inovasi sehingga permasalahan yang ada belum mendapatkan solusi serta tidak ada tindaklanjut untuk menyelesaikan permasalahan

8. Perencanaan inovasi merupakan proses pembelajaran yang melibatkan sumber maupun penerima pesan. Khalayak sasaran sebagai penerima pesan harus diberi kesempatan untuk belajar mengumpulkan fakta dan keadaan agar dapat merumuskan masalah yang dihadapi dan mencari cara pensolusian masalahnya. Setelah diamati peneliti Bengkulu news.co.id belum atau tidak memberikan kesempatan khalayak sasaran berpratisipasi dalam merumuskan masalah yang dihadapi guna menyelesaikan masalah. sehingga Bengkulu news.co.id tidak mengetahui kebutuhan secara utuh yang di inginkan khalayak sasaran.

9. Perencanaan merupakan proses koordinasi yang melibatkan semua pihak. Setelah diamati peneliti Bengkulu news.co.id telah melakukan kordinasi kepada pihak pihak yang terkait tetapi inovasi yang dilakukan belum di terapkan secara utuh dan maksimal 
10. Perencanaan harus memberi kesempatan adanya pelaksanaan evaluasi, baik evaluasi proses maupun evaluasi hasil pelaksanaan. Setelah diamati peneliti Bengkulu news.co.id sudah melakukan evaluasi baik itu kinerja maupun target yang di capai namun hingga kini hanya sebatas evaluasi tetapi realisasinya belum berjalan pada sepenuhnya. Dari paparan diatas peneliti menyimpulkan bahwa inovasi media online dalam mengahadapi persaingan media massa kota Bengkulu belum terealisasi atau berjalan sesuai apa yang di inginkan pemilik perusahaan.

\section{PENUTUP}

Berdasarkan hasil penelitian dan pembahasan yang telah diperoleh selama melakukan penelitian di Bengkulu news.co.id maka disimpulkan ternyata Bengkulu News.dilihat dalam tampilan pemberitaannya dan kolom halaman yang di milikinya telah melakukan inovosi yakni salah satunya telah memiliki ciri khas mengenai tampilan dalam halaman yang di sajikan untuk masyarakat dan public dan selain itu jika di bandingkan dengan media online lain yang ada di Kota Bengkulu, Bengkulu News.co.id menyasikan halam dan rublik yang terinci dan terlengkap rublik atau halaman yang di sajikan mengenai pemberitaan,sehingga dengan terinci dan terlengkap yang di sajikan maka pembaca dan masyarakat juga tidak binggung membuka halaman pemberitaan yang di sediakan oleh Bengkulu News.co.id.

Selain itu dalam tampilan yang lebih lengkap dan memiliki ciri khas yang terinci dalam tayangan pemberitaan yang disajikan hal ini membuat para pengunjung tidak merasa kesulitan dalam mengakses portal web Bengkulu News.co.id dan sehingga banyak pengunjung yang melihat dan mengakses tayangannya tersebut dan untuk kalangan yang yang mengunjung bisa di katagorikan dari kalangan pemeritahan setempat yang mengkses pemberitaan Bengkulu News.co.id.

Ada beberapa saran yang harus dilakukan oleh Bengkulu news.co.id

1. Tampilan kolom berita harus memiliki ciri khas tersendiri supaya kolom berita yang dimuat bisa memiliki nilai berita sehingga public atau pembaca mudah mengingat.

2. Berita yang disebarluaskan oleh Bengkulu news.coid harus berimbang dan independent dan fakta yang akurat. sehingga Bengkulu news.co.id menjadi media yang refensi dan acuan bagi masyarakat yang ada di Kota Bengkulu.

3. Bengkulu news.co.id harus memikirkan SDM yang mmemiliki loyalitas yang tinggi, supaya dapat bekerja secara professional.

\section{DAFTAR PUSTAKA}

Asep, Syamsul dan M.Romli. 2012. Jurnalistik Online : Panduan Mengelola Media Online. Nuansa Bandung

Syarifudin, Yunus. 2010. Jurnalistik Terapan ; Media Online. Grafindo

Severin. 2005. Jurnalistik Online: Panduan Mengelola Media Online. Nuansa, Bandung

Syarifudin, Yunus. 2010. Jurnalistik Terapan. Grafindo, Jakarta

Asep Syamsul, M. Romli. 2012. Jurnalistik Online. Nuansa, Bandung

Zabidina. 2014. pengertian-media-online dan Rizalhermawan. weebly.com/Persaingan-mediamassa.Stephen Robbins 06/2015.dan Zabidina.10/2014, Pengertian-kreativitas-daninovasi beserta Pengertian Media Online 
Shintanurimansari.2013. Persaingan-bisnismedia.

kompasiana.com/ansara/inovasidalam-jurnalisme massa

Indrafirman,

maulana,2013,Persaingan-bisnismedia-massa.html atau komunikasi, 2011/08/Persaingan-antarmedia
Rizal, hermawan.weebly,2011,Persainganmedia-massa.html Rizal, Hermawan. Persaingan Media Massa

(http://rizalhermawan.weebly.com/pe rsaingan-media-massa.html)

Indra, Firman. Maulana. 2013. Persaingan Bisnis Media Massa

(http://indrafirmanmaulana,blogspot.c o.id/2013/10/persaingan-mediamassa.html) 